\title{
The Investigation of Predictors of Cyberbullying and Cyber Victimization in High School and University Students
}

\begin{abstract}
Information and communication technologies catch the attention of people via media that some problems like cyber bullying and cyber victimization are also increased with technological developments. The aim of this study is to examine the effects of gender, frequency of internet usage, perceived academic achievement on cyber bullying, and victimization. The research sample consisted of 151 (76 female, 75 male) high school and university students. Demographic Information Form, Cyber Bullying and Cyber Victimization Scales were administered to the participants. According to the results of the Mann Whitney U-test, males were more likely to be cyberbulliers than females; however, they were also more likely to be victims. In the correlational analysis, it was determined that cyberbullying correlated positively with cybervictimization. Furthermore, multi regression analysis showed that cyberbullying was predicted by perceived academic achievement. However, the results of the multi regression analysis indicated that cybervictimization was predicted by frequency of internet usage.
\end{abstract}

Keywords: cyber bullying, cyber victimization, frequency of internet use, perceived academic achievement
Volume 4 Issue 5 - 2017

\author{
Gizem Akcan,' Erdinc Ozturk ${ }^{2}$ \\ 'Department of Psychology, Istanbul Arel University, Istanbul, \\ Turkey \\ ${ }^{2}$ Department of Social Sciences, Institude of Forensic Medicine, \\ Istanbul University, Turkey
}

\begin{abstract}
Correspondence: Gizem Akcan, Department of Psychology, Istanbul Arel University, Istanbul, Kemalpasa Mahallesi, Halkali Caddesi No: I0I 34295,Turkey, Tel 90 5424560807,
\end{abstract} Email akcan.gizem@hotmail.com

Received: April 21, 2017 | Published: May 02, 2017

\section{Introduction}

Technological developments provide some opportunities like discovering the world, learning and having fun. ${ }^{1}$ Also, technological developments catch attention of people via media. Moreover, they cause the easily access to some web sites that are related with sex, violence, substance use. ${ }^{2}$ Although information and communication technologies provide new, comfortable and useful places, they cause some problems like cyber bullying and cyber victimization. ${ }^{3}$ Some researches supported that cyber victimization causes unjust suffering. People are subjected to harmful behaviors via information and communication technologies and they have both financial and emotional damage. ${ }^{4}$ People who are cyber victims reported that their experiences were very stressful. ${ }^{3}$ Cyber bullying is defined as using information and communication technologies repeatedly to harm people intentionally. ${ }^{2}$ It can be said that cyber bullying harm people via SMS (Short Message Service), taking photo and video with mobile phone camera, harassing people via mobile phone, chat rooms, e-mail, web sites. ${ }^{5}$ Keith et al., ${ }^{6}$ supported that girls are more prone to be cyber bullier than boys. Wolak and etc. (2007) also supported the idea that cyber bulliers are generally girls. ${ }^{6,7}$ However, Erdur-Baker et al. ${ }^{8}$ thought that boys are more prone to be cyber bulliers than girls. ${ }^{8}$ Besides them, according to Hinduja et al., ${ }^{9}$ there is not significant difference between boys and girls in terms of cyber bullying. ${ }^{9}$ In terms of cyber victimization, girls experience more cyber victimization than boys. ${ }^{10}$ Morever, according to some studies there is not significant difference between boys and girls in terms of cyber victimization. ${ }^{11}$

Besides, academic achievement affects all lives of adolescents. Huang et al., ${ }^{12}$ supported that academic achievement does not have significant effect on cyber bullying. ${ }^{12}$ Eroglu et al., ${ }^{13}$ supported that academic achievement is the important predictor of both cyber bullying and cyber victimization. ${ }^{13}$ It can be said that lower academic achievement is a risk factor for being cyber victim. ${ }^{10}$ Beran and $\mathrm{Li}$ (2005) found that cyber victimization and academic achievement have significant relationship. ${ }^{1}$ Furthermore, Ceyhan, Ceyhan et al., ${ }^{14}$ said that the duration of internet use is also related with being cyber bullier and cyber victim that if duration of internet use is too long, the effects of cyber bullying and cyber victimization will increase. ${ }^{14}$ Ybarra et al. ${ }^{15}$ also supported that internet use is the important predictor of both cyber victimization and cyber bullying. ${ }^{15}$

\section{Method}

\section{Participants}

This study is a quantitative study and descriptive method was used. Participants were included from high school and university students who live in Istanbul. This study was applied to 151 (76 female and 75 male) students who study in Bakırkoy High School and Halic University, Istanbul University in Psychology Department, Computer Engineering Department and Department of Business 1, 2, 3, 4 classes and in 2015-2016 school year. Students participated to the study voluntarily. The ages of participants are between 18 and 25 .

\section{Measures}

Demographic Information Form, Cyber Bullying and Cyber Victimization Scales were applied to students. Demographic Information Form was developed by the researcher. Cyber Bullying and Cyber Victimization Scales were developed by Aricak et al., ${ }^{4}$ SPSS 17.0 program was used to analyze the data. ${ }^{4}$

\section{Procedure and data analysis}

To test whether cyber bullying and cyber victimization are related with gender or not, Mann Whitney U Test was used. Moreover, correlational analysis was applied to determine the the relationship between cyber bullying and cyber victimization. Furthermore, multi regression analysis was applied to determine the predictors of cyber bullying and cyber victimization (Table 1). 
Table I Gender of participants

\begin{tabular}{lllll}
\hline Group & Frequency & Percent & Valid Percent & Cumulative Percent \\
\hline Female & 76 & 50.3 & 50.3 & 50.3 \\
Male & 75 & 49.7 & 49.7 & 100 \\
Total & 151 & 100 & 100 & \\
\hline
\end{tabular}

\section{Results}

Totally, 151 ( 75 male and 75 female) students were participated to the study. The ages of them are between 18 and 35 (Table 2). 17 high school and 134 university students participated to this study (Table 3). There is significant difference between male and female in terms of cyber victimization, $U=780, p<0.05$. Cyber victimization scores of males are higher than females (Table 4). There is significant diffrence between males and females in terms of cyber bullying, $U=2000.500$, $p<0.05$. The cyber bullying scres of males are higher than females (Table 5). According to Table 3, there is signifficant and positive relationship between cyber bullying and cyber victimization $(\mathrm{r}=.174$,
$* * \mathrm{p}<.05)$ (Table 6). There is moderate and signifficant correlation between duration of internet usage, academic achievement, gender and cyber bullying, $\mathrm{R}=0.503, \mathrm{R}^{2}=0.253$. Three variables together predict $\% 25$ of cyber bullying. According to standardized regression coefficients $(\beta)$, only percieved academic achievement has signifficant effect on cyber bullying $(\beta=0.460, \mathrm{t}=6.388, \mathrm{p}=0.000)$ (Table 7 ). There is high and signifficant correlation between duration of internet use, academic achievement, gender and cyber victimization, $\mathrm{R}=0.954, \mathrm{R}^{2}=0.910$. Three variables together predict $\% 91$ of cyber victimization. According to standardized regression coefficients $(\beta)$, only duration of internet use has signifficant effect on cyber bullying $(\beta=.944 \mathrm{t}=34.828, \mathrm{p}=.000)$.

Table 2 Education of participants

\begin{tabular}{lllll}
\hline Group & Frequency & Percent & Valid Percent & Cumulative Percent \\
\hline High School & 17 & 11.3 & 11.3 & 11.3 \\
University & 134 & 88.7 & 88.7 & 100 \\
Total & 151 & 100 & 100 & \\
\hline
\end{tabular}

Table 3 Differentiation of cyber victimization according to Gender

\begin{tabular}{llllll}
\hline Group & $\mathbf{n}$ & Mean of Row & Sum of Row & $\mathbf{U}$ & $\mathbf{P}$ \\
\hline Female & 76 & 52.5 & 3150 & 1320 & 0 \\
Male & 75 & 90.83 & 8175 & & \\
\hline
\end{tabular}

Table 4 Differentiation of cyber bullying according to gender

\begin{tabular}{llllll}
\hline Group & $\mathbf{n}$ & Mean of Row & Sum of Row & U & P \\
\hline Female & 76 & 64.82 & 4926.5 & 2000.5 & 0 \\
Male & 75 & 87.33 & 6549.5 & & \\
\hline
\end{tabular}

Table 5 Pearson correlation analysis

\begin{tabular}{llll}
\hline S. No & Variables & I & $\mathbf{2}$ \\
\hline 1 & Cyber Bullying & - & $0.174^{*}$ \\
2 & CyberVictimization & $0.174^{*}$ & - \\
\hline
\end{tabular}

$* * p<0.05$

Table 6 Multiple regression analysis as predictors of cyber bullying

\begin{tabular}{llllll}
\hline Variables & B & Standard Deviation & $\boldsymbol{\beta}$ & $\mathbf{t}$ & $\mathbf{P}$ \\
\hline Constant & 26.539 & 1.361 & - & 19,503 & 0 \\
Duration of Internet Usage (hour) & 0.336 & 0.22 & 0.12 & 1.529 & 0.128 \\
Percieved Academic Achievement & 2.322 & 0.364 & 0.46 & 6.388 & 0 \\
Gender & 0.464 & 0.687 & 0.053 & 0.676 & 0.5 \\
$\mathrm{R}=0.503$ & $\mathrm{R} 2=0.253$ & & & & \\
$\mathrm{~F}(3,147)=16.569$ & $\mathrm{P}=0.000$ & & & &
\end{tabular}

Citation: Akcan G, Ozturk E. The Investigation of Predictors of Cyberbullying and Cyber Victimization in High School and University Students. Forensic Res Criminol Int J. 2017;4(5):I46-149. DOI: 10.15406/frcij.2017.04.00128 
Table 7 Multiple regression analysis as predictors of cyber victimization

\begin{tabular}{llllll}
\hline Variables & B & $\begin{array}{l}\text { Standart } \\
\text { Deviation }\end{array}$ & $\boldsymbol{\beta}$ & $\mathbf{t}$ & $\mathbf{p}$ \\
\hline Constant & 21.229 & 0.891 & - & 23.813 & 0 \\
Duration of Internet Usage (hour) & 5.02 & 0.144 & 0.944 & 34.828 & 0 \\
Percieved Academic Achievement & -0.057 & 0.238 & -0.006 & -0.24 & $0.81 \mathrm{I}$ \\
Gender & 0.444 & 0.45 & 0.027 & 0.986 & 0.326 \\
$\mathrm{R}=0.954$ & $\mathrm{R} 2=0.910$ & & & & \\
$\mathrm{~F}(3,147)=497.342$ & $\mathrm{p}=0.000$ & & & & \\
\hline
\end{tabular}

\section{Discussion}

Campbell supported that cyber bullying has been common in all over the world especially in England, ABD, Canada, and Japan. ${ }^{16}$ Furthermore, according to the results of a study, cyber bullying and cyber victimization have negative effects on psychosocial development and academic achievement of youths. ${ }^{1}$ Moreover, Sahin et al., ${ }^{17}$ also found that cyber bullying damages personal, social, emotional and psychological development of teenagers. ${ }^{17}$ According to the results of this study, cyber bullying scores of boys are higher than girls. It can be said that boys are more prone to be cyber bullier than girls. Peker et al., ${ }^{18}$ also supported this finding that boys experience more cyber bullying than girls. ${ }^{18}$ However, according to Eroglu et al., ${ }^{19}$ girls bully more than boys. ${ }^{19}$ However, there are some studies in the literature that support that there is not significant difference between boys and girls according to cyber bullying. ${ }^{9}$ Moreover, according to the results of this study, there is significant difference between boys and girls according to cyber victimization. Boys are experienced more cyber victimization than girls. Wolak ${ }^{7}$ also supported this finding that boys are more prone to be cyber victim than girls. ${ }^{7}$ However, there are some different findings that girls experience more cyber victimization than boys. ${ }^{20}$ Besides them, according to some studies, there are not significant difference between boys and girls in terms of cyber victimization. ${ }^{11}$ Cyber bullying consists relational bullying types that can be the reason of the differences between research findings. In Turkey, boys and girls have different socializing processes that can be the another reason of this finding. Girls are brought up under inspection and girls are expected to control their aggressive attitudes in Turkey. ${ }^{21}$ That's why girls cannot behave aggressively in daily life and they try to compansate this situation with cyber bulliying.

According to the results of this study, percieved academic achievement has signifficant effect on only cyber bullying. Academic achievement of cyber bulliers are higher than others. The research that was organized by $\mathrm{Li}^{22}$ supported this finding that $34 \%$ of cyber bulliers have higher academic achievement than average, $57 \%$ of them have average academic achievement and $4 \%$ of them have lower academic achievement than average. ${ }^{22}$ Moreover, $48 \%$ of cyber victims have higher academic achievement than average $2 \%$ of them have lower academic achievement than average. Besides them Mitchell ${ }^{23}$ supported that academic achievement does not have significant effect on both cyber bullying and cyber victimization..$^{23}$ Besides them, it was found in this study that only duration of internet use has significant effect on cyber bullying. Erdur-Baker et al., ${ }^{8}$ supported that there is significant relationship between internet use and cyber victimization and cyber bullying. ${ }^{8}$ However, $\mathrm{Li}^{24}$ found that there is significant but low relationship between internet use and cyber bullying. Moreover according to $\mathrm{Li}^{24}$ there is not significant relationship between cyber victimization and duration of internet use. ${ }^{24}$ Preventing and coping programs should be developed to protect students from negative effects of cyber bullying. Instead of waiting the progress of problem, trying to prevent the problems at the beginning will be helpful to protect students from cyber bullying. Prevention is better than acting after the events that it will be helpful to protect students from emotional and economical effects of bullying. Furthermore, it can be said that getting information about the features of cyber bullying will be helpful and effective to develop prevention and coping programs. Besides them, $\mathrm{Li}^{22}$ supported that preventing and coping programs should be organized with participation of school, family and society. ${ }^{22}$

\section{Acknowledgments}

None.

\section{Conflicts of interest}

The author declares there are no conflicts of interest.

\section{References}

1. Beran T, Li Q. Cyber-harassment: A study of a new method for an old behavior. Journal of educational Computing Research. 2005;32(3):265277.

2. Dehue F, Bolman C, Völlink T. Cyberbullying: Youngsters' experiences and parental perception. Cyberpsychol Behav. 2008;11(2):217-223.

3. Neary A, Joseph S. Peer victimization and its relationship to selfconcept and depression among schoolgirls. Personality and Individual Differences. 1994;16(1):183-186.

4. Aricak OT, Kinay H, Tanrikulu T. Siber zorbalık ölçeğinin ilk psikometrik bulgulari. Hasan Âli Yücel Eğitim Fakültesi Dergisi. 2011;9(1):101-114.

5. Smith PK, Mahdavi J, Carvalho M, et al. Cyberbullying: Its nature and impact in secondary school pupils. J Child Psychol Psychiatry. 2008;49(4):376-385.

6. Keith S, Martin ME. Cyber bullying: Creating culture of respect in a cyber World. Reclaiming Children and Youth. 2005;13(4):224-228.

7. Wolak J, Mitchell KJ, Finkelhor D. Does online harassment constitute bullying? An exploration of online harassment by known peers and onlineonly contacts. J Adolesc Health. 2007;41(6 Suppl 1):51-58.

8. Erdur Baker O, Kavşut F. Cyber bullying: A new face of peer bullying. Journal of Euroasian Educational Research. 2007;27(27):31-42.

9. Hinduja S, Patchin JW. Bullying, cyberbullying, and suicide. Arch Suicide Res. 2010;14(3):206-221.

10. Kowalski RM, Limber SP. Electronic bullying among middle school students. J Adolesc Health. 2007;41(6 Suppl 1):22-30. 
11. Topçu C, Erdur Baker O, Capa Aydin Y. Examination of cyber bullying experiences among Turkish students from different school types. Cyberpsychol Behav. 2008;11(6):643-648.

12. Huang Y, Chou C. An analysis of multiple factors of cyber bullying among junior high school students in Taiwan. Computers in Human Behavior. 2010;26(6):1581-1590.

13. Eroğlu Y. Koşullu öz-değer riskli internet davranişlari ve siber zorbalik/ mağduriyet arasındaki ilişkinin incelenmesi. Sakarya University Journal of Education. 2011;5(3):118-129.

14. Ceyhan E, Ceyhan AA, Gürcan A. The validity and reability of the problematic internet usage scale. Educational Sciences: Theory And Practice. . 2007;7(1):411-416.

15. Ybarra ML, Mitchell KJ. Online agressor/ targerts, aggressors, and targetst: A comparison of associated youth characteristics. J Child Psychol Psychiatry. 2004;45(7):1308-1316.

16. Campbell MA. Cyberbullying: An old problem in a new guise? Australian Journal of Guidance and Counseling. 2005;15(1):68-76.

17. Sahin M, Aydın B, Sari SV. Cyberbullying, cyber victimization and psychological symptoms: A study in adolescent. Cukurova University Faculty of Eduction Journal. 2012;41(1):53-59.
18. Peker A, Eroğlu Y, Çitemel N. Boyun eğici davranışlar ile siber zorbalik ve siber mağduriyet arasindaki ilișkide cinsiyetin araciliğının incelenmesi. Uluslararası İnsan Bilimleri Dergisi. 2012;9(1):205-221.

19. Eroğlu Y, Aktepe E, Akbaba S, et al. Siber zorbalık ve mağduriyetin yaygınlığının ve risk faktörlerinin incelenmesi. Eğitim ve Bilim. 2015;40(177):93-107.

20. Mesch GS. Parental mediation, online activities, and cyberbullying. Cyberpsychol Behav. 2009;12(4):387-393.

21. Baran B, Keskin E, Şenol GENÇ. Öğretmen Adaylarının Facebook’ta Zorbalik Yapma Ve zorbalığa maruz kalma durumlarinin bazı değişkenlere göre incelenmesi. Journal of Instructional Technologies \& Teacher Education. 2014;3(1):34-43.

22. Li Q. Bullying in the new playground: Research into cyberbullying and cyber victimisation. Australasian Journal of Educational Technology. 2007;23(4):435-454.

23. Mitchell MS. Cyberbullying and academic achievement: research into the rates of incidence, knowledge of consequences, and behavioral patterns of cyberbullyin. University of Connecticut, USA. 2011.

24. Li Q. Cyber harassment: A study of new method for an old behavior. Journal of Educational Computing Research. 2005;32(3):265-277. 